ISSN 0258-7122 (Print), 2408-8293 (Online)

Bangladesh J. Agril. Res. 44(4): 599-607, December 2019

\title{
EFFECTS OF POTASSIUM APPLICATION ON YIELD ATTRIBUTES, YIELD AND GRAIN QUALITY OF LENTIL IN TERRACE SOIL OF JOYDEBPUR
}

\author{
M. A. Quddus ${ }^{1}$, M. A. Hossain ${ }^{2}$, H. M. NASER ${ }^{3}$ AND S. AKTAR ${ }^{4}$
}

\begin{abstract}
An experiment was conducted in the research field of Pulses Research Sub-Station, BARI, Gazipur during two consecutive years of 2015-16 and 2016-17 to determine the suitable dose of potassium for achieving higher yield attributes, nodulation, nutrient concentration and yield maximization of lentil. There were 5 treatments viz. $\mathrm{T}_{1}=\mathrm{Control}$, $\mathrm{T}_{2}=30 \mathrm{~kg} \mathrm{~K} \mathrm{ha}^{-1}, \mathrm{~T}_{3}=40 \mathrm{~kg} \mathrm{~K} \mathrm{ha}^{-1}, \mathrm{~T}_{4}=50 \mathrm{~kg} \mathrm{~K} \mathrm{ha}^{-1}$ and $\mathrm{T}_{5}=60 \mathrm{~kg} \mathrm{~K} \mathrm{ha}^{-1}$ along with the blanket dose of fertilizers of $\mathrm{N}, \mathrm{P}, \mathrm{S}, \mathrm{Zn}$ and $\mathrm{B} @ 15,20,10,2$ and $1.5 \mathrm{~kg} \mathrm{ha}^{-1}$, respectively for all treatments. The experiment was laid out in randomized complete block design (RCBD) with three replications. Results revealed that the highest seed yield $(1092 \mathrm{~kg}$ $\mathrm{ha}^{-1}$ ) of lentil (mean of two years) was found in $\mathrm{T}_{4}$ followed by $\mathrm{T}_{5}$ treatment and the lowest $\left(736 \mathrm{~kg} \mathrm{ha}^{-1}\right)$ was noted in $\mathrm{K}$ control $\left(\mathrm{T}_{1}\right)$ treatment. The highest $\%$ yield increase over control $(48.3 \%)$ was recorded from $\mathrm{T}_{4}$ treatment. The maximum nodulation was found in $\mathrm{T}_{5}$ followed by $\mathrm{T}_{4}$ treatment. The highest protein $(26.9 \%), \mathrm{N}, \mathrm{P}, \mathrm{K}, \mathrm{S}, \mathrm{Zn}$ and $\mathrm{B}$ concentrations of lentil seed were recorded in $\mathrm{T}_{4}$ treatment. Therefore, the results suggest that the appliction of $50 \mathrm{~kg} \mathrm{~K}$ ha $^{-1}$ along with $\mathrm{N}_{15} \mathrm{P}_{20} \mathrm{~S}_{10} \mathrm{Zn}_{2} \mathrm{~B}_{1.5} \mathrm{~kg} \mathrm{ha}^{-1}$ are optimum for achieving higher yield potential of lentil in terrace soils of Bangladesh.
\end{abstract}

Keywords: Potassium, lentil yield, nodulation, nutrient content, terrace soil

\section{Introduction}

Improved variety and intensive cropping followed by imbalanced use of fertilizers make the soils deficient in nutrients and thus the crops grown on such soils show mineral deficiencies. Deficiency of several major and minor nutrients such as K, S, Ca, Zn, Fe and B are increasing with time (Kurhade et al., 2015; Rao and Vittal, 2007). Lentil (Lens culinaris Medic) is an edible and popular pulse crop that belongs to the family Fabaceae. Lentil seed contains $25 \%$ protein, $1.1 \%$ fat, $59 \%$ carbohydrate, and is also rich in important vitamins, minerals, and soluble and insoluble dietary fiber (Islam et al., 2018). It helps to improve the soil fertility through biological nitrogen fixation (Quddus et al., 2014). The average yield of lentil in Bangladesh is low $\left(752 \mathrm{~kg} \mathrm{ha}^{-1}\right)$ due to non-judicious use of manures and fertilizers (Zahan et al., 2009).

Potassium (K), as a plant nutrient, is becoming increasingly important in Bangladesh and shows a good response to pulse crop. Potassium improves

${ }^{1}$ Senior Scientific Officer, Soil and Water Management Section, HRC, Bangladesh Agricultural Research Institute (BARI), Gazipur, ${ }^{2}$ Chief Scientific Officer, Soil Science Division, BARI, Gazipur, ${ }^{3}$ Principal Scientific Officer, Soil Science Division, BARI, Gazipur, ${ }^{4}$ Scientific Officer, Pulses Research Sub-Station, BARI, Gazipur, Bangladesh. 
plant water relationship and improves shoot growth of pulse crop (Kabir et al., 2004). It maintains turgor pressure of cell which is necessary for cell expansion. It helps in osmo-regulation of plant cell, assists in opening and closing of stomata (Yang et al., 2004). Potassium nutrition is associated with the nodulation and grain quality and protein content (Srinivasarao et al., 2003). It also helps improve disease resistance, drought stress, tolerance to water stress, winter hardiness, tolerance to plant pests and uptake efficiency of other nutrients (Gupta et al., 2013). Considering its nutritional value; it is necessary to uplift the production level and nutritional quality of lentil. Therefore, the present study was undertaken to find out the suitable dose of $\mathrm{K}$ for yield maximization of lentil.

\section{Materials and Methods}

Field experiment was conducted in Rabi season of 2015-16 and 2016-17 in the research field of Pulses Research Sub-Station, Bangladesh Agricultural Research Institute (BARI), Gazipur (24 $0^{\prime} 13^{\prime \prime} \mathrm{N}$ latitude and $90^{\circ} 25^{\prime} 0^{\prime \prime} \mathrm{E}$ longitude). Gazipur is medium high land with fine-textured (clay loam) terrace soils. It belongs to Chhiata series (Soil taxonomy: Udic Rhodustalf) under the agroecological zone - Madhupur Tract (AEZ-28). The Gazipur area received average rainfall from 1.40 to $118 \mathrm{~mm}$ during October to March. The mean minimum and maximum air temperatures during October to March of the experiment were $12.2 \& 33.1^{\circ} \mathrm{C}$ during $2015-16$ and $13.6 \& 33.1^{\circ} \mathrm{C}$, respectively during 2016-17. The average minimum and maximum humidity (\%) were 51 and 88 during October to March (Table 1). Before starting the experiment, initial soil $(0-15 \mathrm{~cm})$ sample was analyzed as outlined by Page et al. (1982) and standard method. The chemical properties are shown in Table 2.

Table 1. Weather data during the experimental period at Gazipur

\begin{tabular}{l|c|c|c|c|c|c|c|c|c|c}
\hline \multirow{2}{*}{ Months } & \multicolumn{3}{|c|}{ Avg. Temperature $\left({ }^{\circ} \mathrm{C}\right)$} & \multicolumn{3}{c|}{ Avg. Humidity (\%) } & \multicolumn{2}{c}{ Rainfall (mm) } \\
\cline { 2 - 10 } & $2015-16$ & \multicolumn{2}{c}{$2016-17$} & \multicolumn{2}{c}{$2015-16$} & $2016-17$ & $2015-16$ & $2016-17$ \\
\cline { 2 - 10 } & Min. & Max. & Min. & Max. & Min. & Max. & Min. & Max. & - & - \\
\hline October & 24.0 & 33.1 & 24.8 & 33.1 & 76 & 83 & 67 & 79 & 14 & 13.7 \\
November & 18.2 & 30.7 & 19.4 & 30.1 & 84 & 88 & 61 & 72 & 0 & 1.40 \\
December & 16.5 & 26.2 & 15.5 & 28.2 & 74 & 82 & 53 & 80 & 0 & 0 \\
January & 12.2 & 25.2 & 13.6 & 27.0 & 67 & 80 & 51 & 81 & 0 & 0 \\
February & 17.0 & 29.6 & 16.3 & 30.4 & 57 & 74 & 46 & 73 & 0 & 0 \\
March & 19.9 & 33.1 & 19.4 & 30.9 & 53 & 73 & 56 & 75 & 118 & 8.02 \\
\hline
\end{tabular}

Source: Weather centre, BARI, Gazipur, Bangladesh 
Table 2. Fertility status of initial soil sample of the experimental field at Gazipur

\begin{tabular}{|c|c|c|c|c|c|c|c|c|c|}
\hline \multirow{2}{*}{ Location } & \multirow{2}{*}{$\mathrm{pH}$} & \multirow{2}{*}{$\begin{array}{l}\mathrm{OM} \\
(\%)\end{array}$} & \multirow{2}{*}{$\begin{array}{c}\text { Total } \\
\mathrm{N} \\
(\%)\end{array}$} & $\mathrm{Ca}$ & $\mathrm{K}$ & $\mathrm{P}$ & $\mathrm{S}$ & $\mathrm{Zn}$ & B \\
\hline & & & & \multicolumn{2}{|c|}{ meq. $100 \mathrm{~g}^{-1}$} & \multicolumn{4}{|c|}{$\mathrm{mg} \mathrm{kg}^{-1}$} \\
\hline $\begin{array}{c}\text { Gazipur } \\
\text { (result) }\end{array}$ & 6.2 & 1.30 & 0.061 & 6.55 & 0.11 & 13 & 13.5 & 0.65 & 0.16 \\
\hline Critical level & - & - & 0.12 & 2.0 & 0.12 & 7 & 10 & 0.60 & 0.20 \\
\hline Interpretation* & acidic & low & $\begin{array}{l}\text { very } \\
\text { low }\end{array}$ & high & low & medium & medium & low & low \\
\hline
\end{tabular}

*FRG, (2012)

The land was firstly opened by a tractor operated chisel plough and then prepared thoroughly by ploughing with a power tillerfollowed by laddering and leveling. There were 5 treatments consisting of different levels of potassium $(0,30,40,50$ \& $60 \mathrm{~kg} \mathrm{~K} \mathrm{ha}^{-1}$ ) including control such as $\mathrm{T}_{1}=$ Control, $\mathrm{T}_{2}=30 \mathrm{~kg} \mathrm{~K} \mathrm{ha}^{-1}, \mathrm{~T}_{3}=40$ $\mathrm{kg} \mathrm{K} \mathrm{ha}^{-1}, \mathrm{~T}_{4}=50 \mathrm{~kg} \mathrm{~K} \mathrm{ha}^{-1}, \mathrm{~T}_{5}=60 \mathrm{~kg} \mathrm{~K} \mathrm{ha}^{-1}$ along with the blanket dose of other nutrients N, P, S, Zn and B @ 15, 20,10, 2 and $1.5 \mathrm{~kg} \mathrm{ha}^{-1}$, respectively.The experiment was laid out in randomized complete block design (RCBD) with three replications. The unit plot size was $12 \mathrm{~m}^{2}$ (4 $\mathrm{m} \times 3 \mathrm{~m}$ ). Nutrients $\mathrm{N}, \mathrm{P}, \mathrm{K}, \mathrm{S}, \mathrm{Zn}$ and $\mathrm{B}$ were applied as urea, TSP, MoP, gypsum, zinc sulphate and boric acid, respectively during final plot preparation. Seeds of lentil (cv. BARI Masur-7) were treated using the fungicide Provex 200 (at $2.5 \mathrm{~g} \mathrm{~kg}^{-1}$ seeds) before sowing for controlling of root rot disease. Treated seeds (@30 kg ha-1) were sown on 09 November, 2015 and 16 November, 2016. Seeds were sown continuously in rows (10 rows/plot) maintaining row to row spacing of $30 \mathrm{~cm}$. Hand weeding as well as thining of seedlings were done at 25 days after sowing (DAS) maintaining the distance of plant to plant $05 \mathrm{~cm}$ by making a total of 800 plants per plot $\left(12 \mathrm{~m}^{2}\right)$. Again, hand weeding was done at 50 DAS. Three sprays were done with fungicide of Rovral starting from 55 DAS to control Stemphylium disease and two times insecticide (Karate @ $2 \mathrm{ml} \mathrm{L}^{-1}$ of water) sprayed at 10 days interval starting from 60 DAS to overcome insect infestation. The crop was harvested at maturity. Data on seed yield $\left(\mathrm{kg} \mathrm{ha}^{-1}\right)$ at around $10 \%$ moisture basis were recorded from the whole plot technique. For stover yield $\left(\mathrm{kg} \mathrm{ha}^{-1}\right)$, mature plants were collected from two $1 \mathrm{~m}^{2}$ quadrates in each plot at harvest time. The yield contributing characters namely: plant height and number of pods plant ${ }^{-1}$ were recorded from ten plants selected randomly from each unit plot. Pods were detached from every plant and the number of pods per plant was counted and averaged. Thousand seed weight $(\mathrm{g})$ was determined by the counting of 500 seeds randomly from each plot and weighing through electronic balance and converting it into 1000-seed weight. For nodule counting per plant, 5 plants from each plot were selected randomly at seedling, vegetative, flowering and podding 
stages. Plants were smoothly uprooted and the soil from roots was removed carefully using tap water. Separated nodules were sliced into two pieces to observe the inside color for nodules activity. The light-pink or red coloured nodules were considered as active.

Stover and seed samples were digested with di-acid mixture $\left(\mathrm{HNO}_{3}-\mathrm{HClO}_{4}\right)(5$ : 1) as described by Piper (1966) for determination of P (spectrophotometer method), $\mathrm{K}$ (atomic absorption spectrophotometer method), S (turbidity method using $\mathrm{BaCl}_{2}$ by spectrophotometer), $\mathrm{Zn}$ (atomic absorption spectrophotometer method, VARIAN SpectrAA 55B, Australia) and B (spectrophotometer following azomethine- $\mathrm{H}$ method) concentration. The $\mathrm{N}$ concentration was determined by Micro-Kjeldahl method. Protein content was calculated multiplying the $\mathrm{N}$ value by 6.25 (Hiller et al., 1948).

Data on yield attributes, number of nodules per plant, protein content and N, P, $\mathrm{K}, \mathrm{S}, \mathrm{Zn}, \mathrm{B}$ content were computed on average of two study years. Data of all parameters were statistically analysed by ANOVA procedure. Then, multiple comparisons were done by LSD at 5\% level (Statistix 10., 1985).

\section{Results and Discussion}

Effects of K application on yield attributes of lentil

The yield attributes of lentil such as plant height, pods per plant and seed weight responded significantly to application of different rates of potassium (Table 3). In the present experiment, plant height varied from 27.2 to $30.7 \mathrm{~cm}$. The tallest plant $(30.7 \mathrm{~cm})$ was recorded from the treatment $\mathrm{T}_{5}$ which was statistically identical with $\mathrm{T}_{4}$ and $\mathrm{T}_{3}$ treatments. The dwarf plant $(27.2 \mathrm{~cm})$ was noted for $\mathrm{K}$ control $\left(\mathrm{T}_{1}\right)$ treatment. The result is in agreement with the findings of Sahay et al. (2013) who observed the maximum plant height of lentil $(43.5 \mathrm{~cm})$ due to application of $90 \mathrm{~kg} \mathrm{~K}_{2} \mathrm{O} \mathrm{ha}^{-1}$. Optimum dose of $\mathrm{K}$ can increase flowering, pod formation, grain set and early physiological maturity (Hasanuzzaman et al., 2018). Different levels of K showed significant effect on the number of pods per plant (Table 3). The maximum number of pods per plant (48.4) was found in the treatment $\mathrm{T}_{4}$ followed by $\mathrm{T}_{5}$ treatment and the minimum number of pods per plant (30.0) was observed in K control $\left(\mathrm{T}_{1}\right)$ treatment (Table 3). Ali et al. (2007) reported on chickpea that application of $150 \mathrm{~kg} \mathrm{~K}_{2} \mathrm{O} \mathrm{ha}^{-1}$ produced significantly maximum number of pods plant ${ }^{-1}$ (61.9). The $\mathrm{K}$ application contributed significantly to the seed weight of lentil. The 1000- seed weight varied from 17.2 to $19.9 \mathrm{~g}$, the highest seed weight being recorded for treatment $\mathrm{T}_{5}$ which was significantly higher than the other treatments. The lowest 1000- seed weight was recorded in $\mathrm{K}$ control treatment (Table 3). Higher K levels resulted in higher seed weight probably due to role of potash in translocation of photosynthates and its 
ability to develop bold seeds (Ali et al., 2007). Islam and Muttaleb (2016) reported that the higher amount of $\mathrm{K}$ helps transfer food material to develop grains.

Table 3. Effects of different levels of $K$ on yield attributes of lentil (pooled data of

\begin{tabular}{l|c|c|c}
\multicolumn{2}{c}{ two years) } \\
\hline Treatment & Plant height $(\mathrm{cm})$ & No. of pods plant & \\
\hline $\mathrm{T}_{1}($ Control $)$ & 27.2 & 30.0 & 1000- seed wt. (g) \\
$\mathrm{T}_{2}\left(30 \mathrm{~kg} \mathrm{~K} \mathrm{ha}^{-1}\right)$ & 29.0 & 38.4 & 17.2 \\
$\mathrm{~T}_{3}\left(40 \mathrm{~kg} \mathrm{~K} \mathrm{ha}^{-1}\right)$ & 29.5 & 39.7 & 18.6 \\
$\mathrm{~T}_{4}\left(50 \mathrm{~kg} \mathrm{~K} \mathrm{ha}^{-1}\right)$ & 29.6 & 48.4 & 19.0 \\
$\mathrm{~T}_{5}\left(60 \mathrm{~kg} \mathrm{~K} \mathrm{ha}^{-1}\right)$ & 30.7 & 44.7 & 19.2 \\
\hline $\mathrm{CV}(\%)$ & 2.84 & 3.14 & 19.9 \\
$\mathrm{LSD}(0.05)$ & 1.56 & 2.38 & 1.71 \\
\hline
\end{tabular}

\section{Effects of $K$ application on yield of lentil}

The seed yield of lentil responded significantly to the application of potassium (Table 4). Potassium involves increasing the utilization of carbohydrates, enhances the dry matter accumulation and ultimately increases the yields of crop (Cheema et al., 2012). The highest seed yield of $1015 \mathrm{~kg} \mathrm{ha}^{-1}$ in the $1^{\text {st }}$ year was recorded from $\mathrm{T}_{4}$ which was significantly higher than other treatments except $\mathrm{T}_{5}$ treatment $\left(994 \mathrm{~kg} \mathrm{ha}^{-1}\right)$. The lowest seed yield value $\left(722 \mathrm{~kg} \mathrm{ha}^{-1}\right)$ being noted in the $K$ control $\left(T_{1}\right)$ treatment. Smilarly in the $2^{\text {nd }}$ year, the significantly highest seed yield $\left(1168 \mathrm{~kg} \mathrm{ha}^{-1}\right)$ was recorded in $\mathrm{T}_{4}$ treatment. The lowest seed yield was observed in $\mathrm{K}$ control treatment (Table 4). Potassium might have regulated the biosynthesis, conversion, and allocation of metabolites that ultimately increased the yield. Many research works support the idea that $\mathrm{K}$ is directly or indirectly responsible for higher yield of crops (Hasanuzzaman et al., 2018). Sahay et al. (2013) reported that grain yield of lentil increased with increase in $\mathrm{K}$ level up to $90 \mathrm{~kg} \mathrm{~K}_{2} \mathrm{O} \mathrm{ha}^{-1}$. Regarding stover yield of lentil, the trend was similar to that of seed yield. The mean stover yield (average of two years) of lentil varied from 1669 to $2542 \mathrm{~kg} \mathrm{ha}^{-1}$. The percent seed yield increase over control varied from 20.8 to $48.3 \%$. The highest seed yield increase noted from $\mathrm{T}_{4}$ treatment was followed by $\mathrm{T}_{5}$ treatment and the lowest from $\mathrm{T}_{2}$ treatment (Table 4). Jahan et al. (2009) reported that $34.2 \%$ grain yield increase of lentil over control was obtained by the application of 42 $\mathrm{kg} \mathrm{K}_{2} \mathrm{O} \mathrm{ha}^{-1}$. 
Table 4. Effects of different levels of $K$ on seed and stover yield of lentil

\begin{tabular}{|c|c|c|c|c|c|c|c|}
\hline \multirow{2}{*}{ Treatment } & \multicolumn{3}{|c|}{ Seed yield $\left(\mathrm{kg} \mathrm{ha}^{-1}\right)$} & \multirow{2}{*}{\begin{tabular}{|c|}
$\%$ yield \\
increase over \\
control
\end{tabular}} & \multicolumn{3}{|c|}{ Stover yield $\left(\mathrm{kg} \mathrm{ha}^{-1}\right)$} \\
\hline & $1^{\text {st }}$ Yr. & $2^{\text {nd }}$ Yr. & mean & & $1^{\text {st }}$ Yr. & $2^{\text {nd }}$ Yr. & Mean \\
\hline $\mathrm{T}_{1}$ (Control) & 722 & 750 & 736 & - & 1793 & 1544 & 1669 \\
\hline $\mathrm{T}_{2}\left(30 \mathrm{~kg} \mathrm{~K} \mathrm{ha}^{-1}\right)$ & 879 & 899 & 889 & 20.8 & 2233 & 1809 & 2021 \\
\hline $\mathrm{T}_{3}\left(40 \mathrm{~kg} \mathrm{~K} \mathrm{ha}^{-1}\right)$ & 949 & 932 & 941 & 27.9 & 2538 & 1871 & 2205 \\
\hline $\mathrm{T}_{4}\left(50 \mathrm{~kg} \mathrm{~K} \mathrm{ha}^{-1}\right)$ & 1015 & 1168 & 1092 & 48.3 & 2816 & 2267 & 2542 \\
\hline $\mathrm{T}_{5}\left(60 \mathrm{~kg} \mathrm{~K} \mathrm{ha}^{-1}\right)$ & 994 & 1022 & 1008 & 36.9 & 2628 & 2073 & 2351 \\
\hline $\mathrm{CV}(\%)$ & 2.03 & 4.74 & - & - & 2.25 & 2.81 & - \\
\hline LSD (0.05) & 34.9 & 85.0 & - & - & 102 & 101 & - \\
\hline
\end{tabular}

\section{Effects of $K$ application on nodulation and protein content of lentil}

Adequate K supply enhances the biological nitrogen (N) fixation (Srinivasarao et al., 2003). Table 5 shows that the number of nodules per plant increased from 32 days after sowing (DAS) to 62 DAS, and then it decreased. Nodulation was influenced significantly due to application of of potassium. At 32 days after sowing, the number of nodules per plant varied from 6.30 to 9.33 , at 47 DAS it ranged from 15.4 to 26.7 , at 62 DAS it was from 15.7 to 27.3 and at 77 DAS, this range varied from 11.1 to 16.9 (Table 5). The maximum number of nodules per plant was recorded from the treatment $\mathrm{T}_{5}$ in all the dates of nodule collection followed by $\mathrm{T}_{4}$ treatment except the collection date 47 (DAS) it was highest in $\mathrm{T}_{4}$ treatment followed by $\mathrm{T}_{5}$ treatment. The lowest number of nodules was found in the $\mathrm{K}$ control treatment (Table 5). The experimental results show that the maximum nodule formation occured during early to mid flowering. After flowering, nodule efficiency was reduced. The result of this study indicates that the different rates of $\mathrm{K}$ application contributed for higher seed protein content in lentil (Table 5). The maximum seed protein (26.9\%) of lentil was found in $\mathrm{T}_{4}$ treatment followed by $\mathrm{T}_{5}, \mathrm{~T}_{3}$ and $\mathrm{T}_{2}$ treatments. The lowest amount $(24.3 \%)$ was found in $\mathrm{K}$ control $\left(\mathrm{T}_{1}\right)$ treatment (Table 5). Similar result was observed by Sahay et al. (2013) who noted that the highest protein content (22.01\%) in lentil grain was obtained by fertilization of $90 \mathrm{~kg} \mathrm{~K}_{2} \mathrm{O} \mathrm{ha}{ }^{-1}$.

Table 5. Effects of different levels of $K$ application on number of nodules per plant and on protein concentration of lentil seed (pooled data of two years)

\begin{tabular}{|c|c|c|c|c|c|}
\hline Treatment & $\begin{array}{c}\text { No. of nodules } \\
32 \text { DAS }\end{array}$ & $\begin{array}{c}\text { No. of nodules } \\
47 \text { DAS }\end{array}$ & $\begin{array}{c}\text { No. of nodules } \\
62 \text { DAS }\end{array}$ & $\begin{array}{c}\text { No. of nodules } \\
77 \text { DAS }\end{array}$ & Protein $(\%)$ \\
\hline $\mathrm{T}_{1}($ Control $)$ & 6.30 & 15.4 & 15.7 & 11.1 & 24.3 \\
\hline $\mathrm{T}_{2}\left(30 \mathrm{~kg} \mathrm{~K} \mathrm{ha} \mathrm{K}^{-1}\right)$ & 7.98 & 23.3 & 23.7 & 15.4 & 26.2 \\
\hline $\mathrm{T}_{3}\left(40 \mathrm{~kg} \mathrm{~K} \mathrm{ha} \mathrm{Ka}^{-1}\right)$ & 8.43 & 24.1 & 24.4 & 15.5 & 26.6 \\
\hline $\mathrm{T}_{4}\left(50 \mathrm{~kg} \mathrm{~K} \mathrm{ha}^{-1}\right)$ & 8.83 & 26.7 & 25.8 & 15.3 & 26.9 \\
\hline $\mathrm{T}_{5}\left(60 \mathrm{~kg} \mathrm{~K} \mathrm{ha}^{-1}\right)$ & 9.33 & 25.6 & 27.3 & 16.9 & 26.8 \\
\hline $\mathrm{CV}(\%)$ & 1.62 & 2.90 & 3.35 & 5.28 & 3.09 \\
\hline LSD (0.05) & 0.25 & 1.26 & 1.47 & 1.48 & 1.53 \\
\hline
\end{tabular}




\section{Effects of $K$ application on nutrient concentration of lentil seed}

Potassium plays a significant regulatory role in numerous plants' physiological processes- seed germination and emergence, protein synthesis, nutrient content and nutrient balance (Marschner, 2012). The N, P, K, S, Zn, and B concentration of lentil (seed) was markedly influenced by the $\mathrm{K}$ application (Tables 6). The highest $\mathrm{N}$ concentration in lentil seed $(4.31 \%)$ was found in the $\mathrm{T}_{4}$ treatment, which was statistically identical to $\mathrm{T}_{5}, \mathrm{~T}_{3}$ and $\mathrm{T}_{2}$ treatments. The lowest seed $\mathrm{N}$ concentration $(3.88 \%)$ was noted from the $\mathrm{K}$ control $\left(\mathrm{T}_{1}\right)$ treatment. In case of $\mathrm{P}$ concentration, the highest $\mathrm{P}$ content in seed $(0.45 \%)$ was recorded in $\mathrm{T}_{5}$ treatment followed by $\mathrm{T}_{4}$ treatment. The lowest $\mathrm{P}$ concentration $(0.31 \%)$ in seed was found in $\mathrm{K}$ control treatment (Table 6). The highest $\mathrm{K}$ concentration in lentil seed $(0.66 \%)$ was recorded from the $\mathrm{T}_{4}$ treatment, which was statistically similar to $\mathrm{T}_{5}$, $\mathrm{T}_{3}$ and $\mathrm{T}_{2}$ treatments. The lowest seed $\mathrm{K}$ concentration $(0.57 \%)$ was found in control $\left(\mathrm{T}_{1}\right)$ treatment (Table 6). Regarding $\mathrm{S}$ concentration, the highest $\mathrm{S}$ concentration in lentil seed $(0.37 \%)$ was recorded in $\mathrm{T}_{5}$ treatment followed by $\mathrm{T}_{4}$ treatment. The lowest $\mathrm{S}$ concentration in seed was found in control $\left(\mathrm{T}_{1}\right)$ treatment (Table 6). The highest $\mathrm{Zn}$ concentration in lentil seed (75.7 ppm) was noted from the $\mathrm{T}_{4}$ treatment. The lowest seed $\mathrm{Zn}$ concentration was noted in the control $\left(\mathrm{T}_{1}\right)$ treatment. The highest B concentration (46.4 ppm) in lentil seed was observed in the $\mathrm{T}_{4}$ treatment, which was statistically similar to $\mathrm{T}_{5}$ treatment. The lowest seed B concentration was estimated from $\mathrm{K}$ control $\left(\mathrm{T}_{1}\right)$ treatment (Table 6). Similar results were reported earlier that the $\mathrm{K}$ application influenced the uptake of $\mathrm{N}, \mathrm{P}$, K, S, Zn, and B (Kurhade et al., 2015; Chaudhari et al., 2018).

Table 6. Effects of different levels of $K$ on nutrient concentration of lentil seed (Pooled data of two years)

\begin{tabular}{l|c|c|c|c|c|c}
\hline \multicolumn{1}{c|}{ Treatment } & $\mathrm{N}(\%)$ & $\mathrm{P}(\%)$ & $\mathrm{K}(\%)$ & $\mathrm{S}(\%)$ & $\mathrm{Zn}(\mathrm{ppm})$ & $\mathrm{B}(\mathrm{ppm})$ \\
\hline $\mathrm{T}_{1}($ Control $)$ & 3.88 & 0.31 & 0.57 & 0.28 & 74.1 & 40.2 \\
$\mathrm{~T}_{2}\left(30 \mathrm{~kg} \mathrm{~K} \mathrm{ha}^{-1}\right)$ & 4.20 & 0.38 & 0.62 & 0.31 & 74.5 & 42.0 \\
$\mathrm{~T}_{3}\left(40 \mathrm{~kg} \mathrm{~K} \mathrm{ha}^{-1}\right)$ & 4.26 & 0.40 & 0.63 & 0.33 & 74.8 & 44.3 \\
$\mathrm{~T}_{4}\left(50 \mathrm{~kg} \mathrm{~K} \mathrm{ha}^{-1}\right)$ & 4.31 & 0.44 & 0.66 & 0.36 & 75.7 & 46.4 \\
$\mathrm{~T}_{5}\left(60 \mathrm{~kg} \mathrm{~K} \mathrm{ha}^{-1}\right)$ & 4.28 & 0.45 & 0.64 & 0.37 & 74.9 & 46.2 \\
\hline $\mathrm{CV}(\%)$ & 3.04 & 4.72 & 4.18 & 3.03 & 1.34 & 2.08 \\
LSD $(0.05)$ & 0.24 & 0.04 & 0.05 & 0.02 & $\mathrm{~ns}$ & 1.72 \\
\hline
\end{tabular}

\section{Conclusion}

Application $50 \mathrm{~kg} \mathrm{~K} \mathrm{ha}^{-1}$ gave the highest seed yield of lentil. The $\mathrm{K}$ application contributed to pod setting, which finally increased the seed yield. The same K rate also showed the highest nutrient and protein content in lentil. Application of $50 \mathrm{~kg} \mathrm{~K} \mathrm{ha}^{-1}$ along with $\mathrm{N}_{15} \mathrm{P}_{20} \mathrm{~S}_{10} \mathrm{Zn}_{2} \mathrm{~B}_{1.5} \mathrm{~kg} \mathrm{ha}^{-1}$ can be recommended for lentil cultivation in terrace soils of Bangladesh. 


\section{References}

Ali, A., M. Ather Nadeem, A.Tanveer, M. Tahir and M. Hussain. 2007. Effect of different potash levels on the growth, yield and protein contents of chickpea (Cicer arietinum L.). Pak. J. Bot., 39(2): 523-527.

Chaudhari, A.V., S.S. Mane and B.R. Chadar. 2018. Effect of graded levels of potassium on growth, yield and quality of black gram. Int. J. Curr. Microbiol .App. Sci., Special Issue-6:1607-1612.

Gupta, K., A. Dey and B. Gupta. 2013. Plant polyamines in abiotic stress responses. Acta Physiologiae Plantarum, 35: 2015-2036.

Hasanuzzaman, M., M. H. M. Borhannuddin Bhuyan, , Kamrun Nahar, Md. Shahadat Hossain, Jubayer Al Mahmud, Md. Shahadat Hossen, Abdul Awal Chowdhury Masud, Moumita and Masayuki Fujita. 2018. Potassium: a vital regulator of plant responses and tolerance to abiotic stresses. Agronomy, doi:10.3390/agronomy8030031

Hiller, A., J. Plazin and D.D.Vanslyke. 1948. A study of conditions of Kjeldhal determination of nitrogen in proteins. J. Biol. Chem., 176(3):1401-1420.

Islam, A. and A. Muttaleb. 2016. Effect of potassium fertilization on yield and potassium nutrition of Boro rice in a wetland ecosystem of Bangladesh. Arch. Agron. Soil Sci., 62: $1530-1540$.

Islam, M.M., M.R. Karim, M.M.H. Oliver, T.A. Urmi, M.A. Hossain, and M.M. Moynul Haque. 2018. Impacts of Trace Element Addition on Lentil (Lens culinaris L.) Agronomy. Agronomy, 8(7): 100; https://doi.org/10.3390/agronomy8070100

Kabir , M. E., M.A. Karim and M.A.K. Azad. 2004. Effect of Potassium on Salinity Tolerance of Mungbean (Vigana radiata L. Wilczek). Journal of Biological Sciences, 4:103-110. DOI: $10.3923 / \mathrm{jbs} .2004 .103 .110$

Kurhade, P.P., H.N. Sethi and R.S. Zadode. 2015. Effect of different levels of potassium on yield, quality, available nutrient and uptake of blackgram. Internat. J. agric. Sci., 11 (1): 175-178. DOI: 10.15740/HAS/IJAS/11.1/175-178

Marschner, H. 2012. Marschner's Mineral Nutrition of Higher Plants, 3rd ed.; Academic Press: London, UK, pp. 178-189.

Page, A.L., R.H. Miller, and D.R. Keeney (Eds.). 1982. Agronomy Series 9 ASA, SSSA. Methods of Soil Analysis (Part 2, 2nd ed., pp. 403-427). Am. Soc. Agron., Madison, USA.

Piper, C.S. 1966. Soil and Plant Analysis. Adelaide University Press, Australia

Quddus, M.A., H.M. Naser, M.A. Hossain and M. Abul Hossain. 2014. Effect of zinc and boron on yield and yield contributing characters of lentil in low Ganges river floodplain soil at madaripur, bangladesh. Bangladesh Journal of Agricultural Research, 39(4): 591-603.

Rao, Ch. Srinivasa and K.P.R. Vittal. 2007. Emerging nutrient deficiencies in different soil types under rainfed production systems of India. Indian J. Fertilizer, 3: 37-46.

Sahay, N., S.P. Singh and V. K. Sharma. 2013. Effect of cobalt and potassium application on growth, yield and nutrient uptake in lentil (Lens culinaris L.). Legume Res., 36 (3): $259-262$. 
Srinivasarao, C., Masood Ali, A.N. Ganeshamurthy, and K.K. Singh. 2003. Potassium Requirements of Pulse Crops. Better Crops International, 17 (1): 8-11.

Statistix 10. 1985. An Analytical Software, Po Box 12185, Tallahassee, FL 32317, Copy right (C) 1985-2013

Yang, X.E., W.M. Wang and He Zi. 2004. Physiological and genetic characteristics of nutrient efficiency of plants in acid soils. p. 78-83.

Zahan, S. A., M. A. Alim, M.M. Hasan, U.K. Kabiraj and M.B. Hossain. 2009. Effect of potassium levels on the growth, yield and yield attributes of lentil. Int. J. Sustain. Crop Prod. 4(6):1-6. 
